\title{
Peran Organizational Well-Being Terhadap Job Involvement Pada Karyawan Produksi PT. XYZ
}

\author{
Sahda Febi Wilendari \\ Fakultas Psikologi, Universitas Padjajaran \\ sahdafebiw@gmail.com \\ Maya Rosmayati Ardiwinata \\ Fakultas Psikologi, Universitas Padjajaran \\ mayardiwi@yahoo.com \\ Nurul Yanuarti \\ Fakultas Psikologi, Universitas Padjajaran \\ nurulyanuarti@yahoo.com
}

\begin{abstract}
The increasing demand for vaccines in Indonesia makes PT. XYZ has high demands for providing vaccines. This makes the performance of the production department being the main key in responding to these needs. Job involvement has a large impact on employee performance. This study aims to see whether there is an influence of organizational well-being on job involvement in the production employees of PT. XYZ. Respondents in this study were 217 production employees at PT. XYZ (209 men, 18 women) aged 26-56 years with a service period of 3-35 years. These results indicate that organizational well-being has significant influence on job involvement of PT. XYZ ( $p=0,000 ; \mathrm{R}=0.557 ; \mathrm{R} 2=$ $0.310)$. These results also indicate that organizational well-being has an influence of $31 \%$ on job involvement, while the remaining $69 \%$ is influenced by other variables not examined in this study.
\end{abstract}

Keywords : organizational well-being; job involvement

\begin{abstract}
Abstrak
Meningkatnya permintaan vaksin dalam negeri membuat PT. XYZ mendapatkan tuntutan yang tinggi untuk menyediakan vaksin. Hal ini membuat kinerja bagian produksi menjadi kunci utama dalam menjawab kebutuhan tersebut. Job involvement memiliki dampak yang besar terhadap kinerja karyawan. Penelitian ini bertujuan untuk melihat apakah terdapat pengaruh organizational well-being terhadap job involvement pada karyawan bagian produksi PT. XYZ. Responden dalam penelitian ini berjumlah 217 orang karyawan produksi di PT. XYZ (209 orang laki-laki, 18 orang perempuan) berusia 26-56 tahun dengan masa kerja 3-35 tahun. Hasil tersebut menunjukkan bahwa organizational well-being memiliki pengaruh yang signifikan terhadap job involvement karyawan produksi PT. XYZ
\end{abstract}


$\left(p=0,000 ; \mathrm{R}=0,557 ; \mathrm{R}^{2=} 0,310\right)$. Selain itu hasil tersebut juga menunjukkan bahwa organizational well-being memiliki pengaruh sebesar $31 \%$ terhadap job involvement sementara $69 \%$ sisanya dipengaruhi oleh variabel lain yang tidak diteliti dalam penelitian ini.

Kata kunci : organizational well-being; job involvement

\section{Pendahuluan}

Penyakit menular semakin banyak bermunculan dan membahayakan kesehatan, hal ini mengakibatkan vaksin menjadi sangat penting untuk dapat mengurangi bahaya dari penyakit menular tersebut. Adanya Kejadian Luar Biasa (KLB) Difteri yang terjadi pada tahun 2017 lalu membuat meningkatnya kesadaran masyarakat akan kebutuhan vaksin. Data dan Informasi Profil Kesehatan Indonesia 2018 per Januari 2019 menunjukkan bahwa capaian imunisasi dasar berada di angka 81,99 \% (Wijaya, 2019). Apabila capaian imunisasi dasar dapat ditingkatkan, maka akan mengurangi kemungkinan munculnya KLB.

Peningkatan capaian imunisasi tersebut membuat PT. XYZ harus dapat memproduksi vaksin dalam jumlah yang tinggi untuk dapat menjawab kebutuhan tersebut. Kegiatan ini sangat bergantung dari kinerja bagian produksi PT. XYZ di mana kegiatan inti dari perusahaan ini juga bergantung pada bidang produksi. Bagian ini bertugas untuk merencanakan seluruh proses produksi mulai dari penggunaan material sampai memastikan target produk secara kuantitas dan kualitas dapat tercapai. Disamping itu salah satu unsur dari bagian ini bertugas untuk memastikan seluruh peralatan terkait produksi terpelihara dengan baik. Bagian ini merupakan ujung tombak keberhasilan sebuah perusahaan. Pendapatan perusahaan sangat bergantung pada kinerja dan produktivitas dari bidang ini, begitu juga kepuasan dari konsumen. Perilaku kerja yang produktif tersebut merupakan tampilan kinerja karyawan yang memiliki dampak positif terhadap tujuan organisasi (Jex \& Britt, 2008). Perilaku produktif dan kinerja yang baik dipengaruhi oleh sikap kerja yang positif. Diantara beberapa sikap kerja, job involvement karyawan yang tinggi memiliki pengaruh yang paling besar terhadap 
pencapaian efektivitas organisasi (Bahjat Abdallah, Yousef Obeidat, Osama Aqqad, Khalil Al Janini, \& Dahiyat, 2017; Lubakaya, 2014). Emery dan Baker menjelaskan job involvement akan meningkatkan produktivitas dalam organisasi dengan mengikat karyawan secara utuh terhadap pekerjaannya dan membuatnya menjadi pengalaman bermakna (Doobree, 2009). Job involvement merupakan kebutuhan pemenuhan kognitif seseorang yang akan membuatnya bekerja lebih keras dalam meningkatkan performanya (Lubakaya, 2014).

Job involvement dipengaruhi oleh kondisi organisasi (terutama yang berhubungan dengan hubungan sosial) (Lodahl \& Kejner, 1965). Farrel dan Rusbult mengungkapkan bahwa orang yang terlibat dengan pekerjaannya atau disebut job involved person dipandang sebagai seseorang yang menganggap pekerjaan merupakan bagian penting dari hidupnya dan sebagai seorang yang sangat dipengaruhi oleh keseluruhan situasi kerjanya, yaitu pekerjaan itu sendiri, rekan kerja, dan organisasi (Doobree, 2009).

Semakin baik persepsi yang dihasilkan karyawan terhadap lingkungan organisasi berhubungan secara positif dengan job involvement, usaha, dan kinerja (Brown \& Leigh, 1996). Brown dan Leigh lebih lanjut menjelaskan bahwa ketika karyawan memersepsi lingkungan organisasi secara positif (konsisten dengan nilai dan minat diri), maka mereka akan semakin dapat ia mengidentifikasikan tujuan personal mereka dengan tujuan organisasi secara umum sehingga mereka akan memberikan usaha yang lebih dalam mencapai hal tersebut. Sebelumnya penelitian yang dilakukan oleh Brown dan Leigh (1996) mengidentifikasi lingkungan kerja dengan psychological climate, namun pada penelitian ini, lingkungan kerja yang diidentifikasi adalah ketika tersedianya lingkungan efektif, reflektif, dan afektif yang disebut sebagai organizational well-being. Mowday, Porters, dan Steers mengungkapkan bahwa organizational well-being yang rendah dalam sebuah organisasi akan menurunkan produktivitas, tingginya absen di kantor, rendahnya motivasi kerja, rendahnya kesediaan untuk bekerja, dan kurangnya kepercayaan dalam organisasi (Colì \& Rissotto, 2015). Organizational well-being memiliki pengaruh terhadap motivasi kerja karyawan yang pada akhirnya memengaruhi produktivitas dan efisiensi di dalam perusahaan secara 
keseluruhan (Colì \& Rissotto, 2015). Organizational well-being mengedepankan lingkungan organisasi melalui keunikan dari organisasi tersebut di mana organisasi tersebut harus dapat memaksimalkan subjective well-being sehingga individu dapat memaksimalkan potensi yang dimilikinya serta menghasilkan efektivitas secara maksimun untuk dirinya maupun untuk organisasi (Cojocaru, 2014)

Kualitas lingkungan di tempat kerja akan memengaruhi motivasi karyawan, kinerja, serta produktivitas (Massoudi \& Hamdi, 2017). Eby, Adams, Russel, dan Gaby menjelaskan bahwa tersedianya sikap positif terhadap lingkungan kerja merupakan aspek yang penting untuk dapat mencapai tujuan organisasi dan dapat berhasil dalam melakukan program perubahan dalam organisasi (Katsaros, Tsirikas, \& Bani, 2014). Oleh sebab itu penelitian ini ingin melihat pengaruh lingkungan kerja yang dalam hal ini dilihat dari organizational well-being terhadap sikap kerja karyawan yaitu job involvement.

\section{Organizational Well-Being}

Organizational well-being dapat didefinisikan sebagai suatu kondisi di mana tersedianya lingkungan yang efektif, reflektif, dan afektif, atau dapat disingkat lingkungan ERA (Prilleltensky \& Prilleltensky, 2006). Lingkungan yang efektif bertujuan untuk menunjang tujuan organisasi, reflektif untuk dapat selalu berupaya melakukan pengembangan diri melalui evaluasi terhadap kinerja perusahaan, dan afektif dimana adanya kondisi saling mendukung dan penuh kasih sayang. Ketiga lingkungan ini saling bergantung satu sama lain, apabila ada salah satu aspek yang tidak ada diantara ketiga aspek ini maka organizational well-being tidak dapat tercipta. Afeksi yang terlalu banyak tanpa adanya refleksi akan mengarah kepada kepuasan, sedangkan terlalu banyak efisiensi tanpa adanya refleksi akan mengarah kepada keadaan pengarahan tanpa kritik. Afeksi yang terlalu sedikit tanpa refleksi akan mengarah kepada pengasingan dan mengabaikan nilai, sedangkan terlalu sedikit efisiensi tanpa refleksi menyebabkan disfungsi (Prilleltensky \& Prilleltensky, 2006). 


\section{Job Involvement}

Lodahl dan Kejner (1965) mendefinisikan job involvement sebagai suatu kondisi di mana karyawan dapat mengidentifikasikan dirinya dengan pekerjaannya secara psikologis, atau seberapa penting pekerjaan tersebut terhadap gambaran diri karyawan secara keseluruhan, dan sejauh mana kinerja karyawan memengaruhi self-esteem. Beberapa penelitian sebelumnya mengungkapkan bahwa karyawan yang memiliki job involvement yang tinggi di mana ia sangat terlibat dengan pekerjaannya akan menempatkan pekerjaannya sebagai pusat dari seluruh minat mereka, sementara karyawan yang memiliki job involvement rendah memiliki fokus minat lain diluar pekerjaannya serta memiliki daya kreativitas dan inovasi yang rendah (Bahjat Abdallah et al., 2017). Lodahl dan Kejner (1965) mengungkapkan terdapat empat dimensi yang memiliki peran penting dalam pembentukan job involvement, yaitu tanggapan karyawan terhadap pekerjaan yang diberikan kepadanya karena merasa pekerjaan tersebut penting bagi dirinya, cara karyawan dalam mengekspresikan keterlibatan kerja yang dirasakannya, tanggung jawab yang dirasakan karyawan terhadap pekerjaan yang dimilikinya, serta perasaan tidak nyaman yang dirasakan karyawan ketika tidak hadir di kantor dan tidak dapat menyelesaikan pekerjaannya.

\section{Metode}

\section{Populasi Dan Sampel}

Populasi dalam penelitian ini adalah karyawan Produksi PT. XYZ yang berjumlah 505 orang, teknik pengambilan sampel pada penelitian ini adalah probability sampling dengan teknik stratified sampling. Kriteria responden penelitian merupakan karyawan yang memiliki status sebagai karyawan tetap dan telah bekerja di PT. XYZ minimal selama 1 tahun. Dengan menggunakan penentuan jumlah sampel minimal berdasarkan tabel Krejcie dan Morgan (1970), diperoleh jumlah sampel minimal dalam penelitian ini adalah 217. Selanjutnya peneliti melakukan perhitungan proporsi untuk setiap level jabatan, yaitu kepala bagian, kepala seksi, ahli madya, staf, staf muda, dan pelaksana. 
Subjek pada penelitian ini berjumlah 227 orang karyawan produksi PT. XYZ (209 orang laki-laki, 18 orang perempuan) berusia 26-56 tahun dengan masa kerja 3-35 tahun. Karyawan yang mengikuti penelitian ini adalah kepala bagian $(n=7)$, kepala seksi $(n=30)$, ahli madya $(n=1)$, ahli muda $(n=2)$, staf $(n=16)$, staf muda $(n=33)$, dan pelaksana (138). Sebagian besar karyawan memiliki latar belakang pendidikan SMA/SMK $(49,3 \%)$ dan sudah menikah $(92,1 \%)$.

Peneliti meminta kesediaan karyawan produksi untuk terlibat dalam penelitian dengan mengisi kuesioner online menggunakan google form dengan mengundang karyawan datang ke ruang asesmen perusahaan sesuai jadwal yang telah ditetapkan.

\section{Alat Ukur}

Pengumpulan data dilakukan dengan menyebarkan kuesioner online menggunakan alat ukur job involvement (Lodahl \& Kejner, 1965) yang telah diadaptasi oleh Rachmah (2016) dengan reliabilitas 0,902 dan validitas berkisar antara 0,281 - 0,682. Alat ukur organizational well-being dikonstruksi oleh peneliti dengan validasi expert judgement berdasarkan dimensi organizational well-being oleh Prilleltensky dan Prilleltensky (2006) yaitu lingkungan efektif, lingkungan reflektif, lingkungan afektif, reliabilitas alat ukur ini 0,954 dan validitas item berikisar antara 0,450 - 0,746.

\section{Analisis Statistik}

Proses analisis data dilakukan dengan menggunakan software SPSS versi 22 for windows dengan menggunakan analisis statistik berupa analisis regresi linear sederhana untuk melihat pengaruh organizational well-being terhadap job involvement.

\section{Hasil dan Pembahasan}

Berdasarkan 227 responden, 69,2 \% responden memiliki skor organizational well-being pada kategori moderat, 30,4 \% responden memiliki skor organizational well-being pada kategori tinggi, sementara sisanya sebanyak $0,2 \%$ berada pada kategori rendah $(M=133,82 ; S D=15,264)$. Hal ini menunjukkan bahwa sebagian besar karyawan memersepsi organisasi sudah cukup mampu 
menghadirkan lingkungan yang efektif, reflektif, dan afektif sehingga karyawan bagian produksi menjadi sejahtera. Lingkungan efektif dipersepsi paling tinggi $(\mathrm{M}=3,09 ; \quad \mathrm{SD}=0,353)$, kemudian diikuti oleh lingkungan afektif $(\mathrm{M}=2,94$; $\mathrm{SD}=0,361)$ dan paling terakhir lingkungan reflektif $(\mathrm{M}=2,78 ; \mathrm{SD}=0,440)$. Hasil ini menunjukkan bahwa lingkungan kerja yang paling dirasakan kehadirannya oleh karyawan produksi adalah adanya lingkungan efektif di mana organisasi menyediakan lingkungan yang dapat menunjang karyawan dalam menjalankan tugasnya dengan efektif dan efisien.

Sementara itu pada job involvement karyawan, dari 227 responden, 57,3\% responden memiliki skor job involvement yang berada pada kategori moderat dan sisanya sebanyak 57,3\% berada pada kategori tinggi $(\mathrm{M}=87,09 ; \mathrm{SD}=7,716)$. Hasil tersebut menunjukkan bahwa sebagian besar karyawan cukup dapat dalam mengidentifikasikan diri secara psikologis dengan pekerjaannya. Karyawan menganggap bahwa hasil pekerjaan cukup memengaruhi self-esteem mereka dan pekerjaan cukup penting bagi gambaran diri mereka secara keseluruhan. Sense of duty towards work merupakan bentuk keterlibatan yang paling tinggi $(\mathrm{M}=3,20$; $\mathrm{SD}=0,322)$, kemudian diikuti oleh response to work $(\mathrm{M}=3,11 ; \mathrm{SD}=0,352)$, feeling guilty about unfinished work and absenteeism $(\mathrm{M}=2,91 ; \mathrm{SD}=0,367)$, dan terakhir expression of being job involved $(\mathrm{M}=2,73 ; \mathrm{SD}=0,310)$. Hasil tersebut menunjukkan bahwa keterlibatan karyawan produksi lebih banyak didasarkan atas adanya rasa tanggung jawab di dalam diri karyawan untuk dapat menyelesaikan pekerjaannya. Tingginya tingkat ketergantungan di dalam pekerjaan direktorat produksi antar satu unit yang dengan unit lainnya membuat karyawan berusaha untuk dapat menyelesaikan pekerjaannya agar tidak menghambat bidang lain sehingga target produksi pada hari tersebut dapat tercapai.

Setelah dilakukan analisis regresi linear sederhana, didapatkan nilai koefisien korelasi $(\mathrm{R})$ sebesar 0,557 dan koefisien determinasi $\left(\mathrm{R}^{2}\right)$ sebesar 0,310 dengan nilai signifikansi $p=0,000(p<0,05)$. Hasil tersebut menunjukkan bahwa terdapat pengaruh yang signifikan antara organizational well-being terhadap job involvement karyawan produksi PT. XYZ. Hasil penelitian juga menunjukkan bahwa bahwa organizational well-being berpengaruh terhadap job involvement 
sebesar $31 \%$, sementara $69 \%$ sisanya dipengaruhi oleh variabel lain yang tidak dijelaskan dalam penelitian ini.

Hasil penelitian menunjukkan bahwa ketika karyawan produksi memersepsi PT. XYZ sebagai organisasi yang mampu menyediakan lingkungan yang efektif dalam menunjang tujuan organisasi, reflektif untuk dapat selalu berupaya melakukan pengembangan diri melalui evaluasi terhadap kinerja perusahaan, dan afektif di mana adanya kondisi saling mendukung dan penuh kasih sayang yang membuat karyawan menjadi sejahtera, maka karyawan produksi PT. XYZ akan dapat mengidentifikasikan dirinya secara psikologis terhadap pekerjaannya, menghayati bahwa pekerjaan merupakan hal yang penting bagi keseluruhan gambaran dirinya, serta kinerja yang dimilikinya akan berpengaruh pada harga dirinya sehingga karyawan akan memberikan usaha terbaik dalam tampilan kerjanya.

Beberapa penelitian sebelumnya mengungkapkan beberapa pengaruh lingkungan kerja terhadap job involvement. Beberapa lingkungan kerja yang memiliki pengaruh kepada job involvement yang sudah diteliti sebelumnya yaitu psychological climate (Brown \& Leigh, 1996), person-environment fit model (Blau, 1987), perceived organizational support (Gorji, Etemadi, \& Hoseini, 2014), dan organizational climate (Kalhor, Khosravizadeh, Moosavi, Heidari, \& Habibi, 2018). Hasil penelitian ini sejalan dengan penelitian sebelumnya yang menyebutkan bahwa lingkungan kerja yang dalam hal ini dimanifestikan sebagai organizational well-being yaitu kondisi ketika hadirnya lingkungan yang efektif, reflektif, dan afektif dapat memengaruhi tingkatan job involvement pada diri karyawan.

Beberapa penelitian sebelumnya menyebutkan bahwa faktor situasional dan karakteristik pekerjaan dapat memengaruhi tingkat keterlibatan karyawan terhadap pekerjaannya (Rabinowitz \& Hall, 1977). Apabila lingkungan kerja dipersepsi dapat memberikan kejelasan tugas, memberikannya otonomi dalam pengerjaan tugas sehingga membuatnya lebih bertanggung jawab, memberikannya rasa aman dalam bekerja, memberikan kesempatan dalam melakukan pengambilan keputusan, memberikannya kesempatan untuk mengembangkan 
keterampilan, mempunyai hubungan interpersonal yang baik dengan sesama karyawan yang disertai adanya dukungan sosial diantara sesama karyawan maka karyawan akan semakin terlibat dengan pekerjaannya. Adanya kejelasan tugas dan adanya rasa aman dalam bekerja yang dirasakan karyawan merupakan tanda dari lingkungan efektif. Tersedianya kesempatan dalam melakukan pengambilan keputusan dan lingkungan kerja yang memberikan kesempatan untuk mengembangkan keterampilan merupakan tanda dari adanya lingkungan reflektif. Sementara itu tersedianya hubungan interpersonal yang baik dengan sesama karyawan yang disertai adanya dukungan sosial diantara sesama karyawan merupakan tanda dari adanya lingkungan afektif.

Hasil penelitian ini hampir sejalan dengan temuan penelitian yang dilakukan oleh Brown dan Leigh (1996). Penelitian tersebut dilakukan untuk melihat hubungan antara pesepsi karyawan terhadap lingkungan organisasi dengan job involvement, effort, dan performance. Lingkungan organisasi pada penelitian tersebut dimanisfestaikan sebagai iklim psikologis yang didefinisikan sebagai bagaimana karyawan memersepsikan lingkungan kerja dan menginterpretasikannya pada well being mereka. Iklim psikologis kemudian berhubungan dengan job involvement yang kemudian menimbulkan usaha atau effort di mana usaha tersebut berhubungan dengan performa kerja yang ditampilkan.

Dalam penelitian ini, persepsi karyawan dimanifestasikan sebagai organizational well-being. Kedua variabel ini mengukur persepsi karyawan terhadap lingkungan organisasi di mana iklim psikologis memersepsikan lingkungan kerja dari sisi manajemen yang suportif, kejelasan peran, kebebasan dalam mengekspresikan diri, persepsi karyawan mengenai kontribusi terhadap tujuan organisasi, rekognisi yang diberikan oleh organisasi, dan tantangan dalam pekerjaan. Sementara organizational well-being memersepsikan lingkungan kerja sebagai lingkungan efektif, reflektif, dan afektif yang diciptakan oleh organisasi. Kedua penelitian ini menunjukkan bahwa persespi karyawan terhadap kondisi dan suasana lingkungan kerja akan berpengaruh terhadap job involvement karyawan. 


\section{Kesimpulan dan Saran}

\section{Kesimpulan}

Berdasarkan penelitian tersebut dapat disimpulkan bahwa Organizational well-being memiliki pengaruh yang signifikan terhadap job involvement karyawan produksi PT. XYZ. Positif atau negatifnya persepsi karyawan terhadap organizational well-being yang dimiliki PT. Bio Farma memiliki pengaruh terhadap tinggi rendahnya job involvement pada diri karyawan. Karyawan produksi PT. XYZ memersepsi lingkungan efektif merupakan lebih tinggi dibandingkan dengan lingkungan afektif dan reflektif. Hal ini menunjukkan bahwa karyawan PT. XYZ memersepsi bahwa lingkungan yang paling dirasakan kehadirannya adalah lingkungan efektif di mana organisasi sudah mampu menyediakan lingkungan yang dapat menunjang kerja yang efisien sehingga tujuan dapat dicapai dengan mengelola pekerjaan, fokus serta bertanggung jawab terhadap tugas sehingga terselesaikan dengan baik. Selain itu karyawan juga cukup dapat menjadi suatu kesatuan dengan pekerjaannya di mana ia menganggap bahwa pekerjaannya merupakan suatu hal yang penting bagi gambaran dirinya serta hasil kerja memengaruhi harga diri dari karyawan. Hal ini menunjukkan bahwa karyawan cukup dapat terlibat dengan pekerjaannya. Keterlibatan karyawan lebih banyak didasarka oleh adanya rasa tanggung jawab di dalam diri karyawan terhadap pekerjaan yang sedang dihadapinya.

\section{Saran}

Perusahaan dapat berupaya meningkatkan ketersediaan lingkungan efektif, reflektif, dan afektif bagi karyawan sehingga persepi karyawan menjadi lebih positif terkait ketersediaan lingkungan tersebut. Hal ini dapat dilakukan dengan berupaya menyeimbangkan value, interest, dan power yang ada pada diri karyawan dan organisasi. Ketiga hal ini merupakan antesenden atau sumber dari terciptanya organizational well-being (Prilleltensky \& Prilleltensky, 2006). Dengan demikian, job involvement karyawan akan meningkat sehingga kinerja yang ditampilkan dapat menjadi lebih optimal. Bagi peneliti selanjutnya dapat dilakukan penelitian lebih lanjut terkait variabel lain yang dapat memperkuat $n j o b$ involvement pada diri karyawan. Variabel lain tersebut adalah variabel sikap kerja 
seperti job satisfaction ataupun organizational commitment. Selain itu perlu dilakukannya analisis tambahan terkait dampak pengaruh organizational wellbeing dan job involvement terhadap perilaku kerja karyawan baik dalam hal produktivitas dan kinerja sehingga pengaruh keduanya menjadi lebih terlihat hasilnya dan dampaknya kepada perusahaan. Hal ini dapat dilakukan dengan melakukan pengukuran terhadap kinerja dan produktivitas karyawan.

\section{DAFTAR PUSTAKA}

Bahjat Abdallah, A., Yousef Obeidat, B., Osama Aqqad, N., Khalil Al Janini, M. N., \& Dahiyat, S. E. (2017). An Integrated Model of Job Involvement, Job Satisfaction and Organizational Commitment: A Structural Analysis in Jordan's Banking Sector. Communications and Network, 09(01), 28-53. https://doi.org/10.4236/cn.2017.91002

Blau, G. J. (1987). Using a Person-Environment Fit Model to Predict Job Involvement and Organizational Commitment. Journal of Vocational Behavior, 257(3), 240-257.

Brown, S. P., \& Leigh, T. W. (1996). A New Look at Psychological Climate and Its Relationship to Job Involvement A New Look at Psychological Climate and Its Relationship to Job Involvement, Effort , and Performance. Journal of Applied Psychology, 81(4), 358-368. https://doi.org/10.1037/00219010.81.4.358

Cojocaru, C. L. (2014). Organizational well-being. Mircea Cel Batran Naval Academy, XVII(2), 112-114.

Colì, E., \& Rissotto, A. (2015). Organizational Well-Being in a Public Research Agency: The Point of View of Administrative Staff and Researchers. Journal of Social Sciences, 11(4), 381-394. https://doi.org/10.3844/jssp.2015.381.394

Doobree, D. (2009). Job Involvement Among Bank Managers In Mauritius (Disertasi Doktor). Diakses melalui https://eprints.usq.edu.au/19734/. (19734).

Gorji, H. A., Etemadi, M., \& Hoseini, F. (2014). Perceived organizational support and job involvement in the Iranian health care system: a case study of emergency room nurses in general hospitals. Journal of education and health 
promotion, 3(58).

Jex, S. M., \& Britt, T. W. (2008). Organizational Psychology: A ScientistPractitioner Approach. United States of America: John Wiley \& Sons, Inc.

Kalhor, R., Khosravizadeh, O., Moosavi, S., Heidari, M., \& Habibi, H. (2018). Role of Organizational Climate in Job Involvement: A Way to Develop the Organizational Commitment of Nursing Staff. Journal of Evidence-Based Integrative Medicine, 23, 1-5. https://doi.org/10.1177/2515690X18790726

Katsaros, K. K., Tsirikas, A. N., \& Bani, S. M. N. (2014). Exploring employees' perceptions, job-related attitudes and characteristics during a planned organizational change. International Journal of Business Science and Applied Management, 9(1), 36-50.

Krejcie, R. V, \& Morgan, D. W. (1970). Determining and psychological measurement. Educational and Psychological Measurement, 30, 607-610.

Lodahl, T., \& Kejner, M. (1965). The definition and measurement of job involvement. Journal of Applied Psychology, 49(1), 24-33. Retrieved from http://dx.doi.org/10.1037/h0021692

Lubakaya, C. W. (2014). Factors Affecting Job Involvement in an Organization: A Case of Nzoia Sugar Company Limited Abstract : 3(6), 77-105.

Massoudi, D. A. H., \& Hamdi, D. S. S. A. (2017). The Consequence of work environment on Employees Productivity. IOSR Journal of Business and Management, 19(01), 35-42. https://doi.org/10.9790/487x-1901033542

Prilleltensky, I., \& Prilleltensky, O. (2006). Promoting Well-Being: Linking Personal, Organizational, and Community Change. United States of America: John Wiley \& Sons, Inc.

Rabinowitz, S., \& Hall, D. T. (1977). Organizational research on job involvement, Psychological Bulletin,. 84(2), 265 - 288.

Rachmah, Annida. (2016). Pengaruh Iklim Psikologis terhadap Job Involvement (Tesis Magister yang Tidak Dipublikasikan). Fakultas Psikologi Universitas Padjajaran, Bandung.

Wijaya, C. (2019, Juni 19). Vaksinasi di Aceh dan beberapa provinsi lain rendah: KLB difteri dan campak 'berpotensi terulang'. BBC News Indonesia. Diakses melalui https://www.bbc.com/indonesia/indonesia-48633226 